\title{
Synovial fluid examination for the diagnosis of synovial amyloidosis in patients with chronic renal failure undergoing haemodialysis
}

\author{
J MUÑOZ-GÓMEZ, ${ }^{1}$ R GÓMEZ-PÉREZ, ${ }^{1}$ M SOLÉ-ARQUES, ${ }^{2}$ AND \\ E LLOPART-BUISÁN ${ }^{1}$
}

From the Departments of ${ }^{1}$ Rheumatology and ${ }^{2}$ Pathology, Hospital Clínico y Provincial, Barcelona, Spai

SUMMARY The diagnosis of synovial amyloidosis is based upon synovial biopsy. Synovial fluiø (SF) in seven patients with amyloid arthropathy associated with chronic renal failure undergoing haemodialysis were studied. The SF and synovial samples of 10 consecutive patients wit $B$ seronegative mono- or oligoarthritis served as a controls. Six of the seven patients with amyloid positive synovial biopsy specimens showed amyloid in their SF. No amyloid was found in tho synovial tissue or fluid of the 10 patients in the control group, the sensitivity being $87 \cdot 7 \%$. The. finding of amyloid in SF was highly reproducible, showing its presence in the same joint ofb several occasions. The deposits were Congophilia resistant to potassium permanganate pretreatment, and the immunohistochemical analysis proved that they contained $\beta_{2}$ microglobub lin. The high sensitivity and good reproducibility of the method shows that the finding of amyloie in SF is sufficient for the diagnosis of synovial amyloidosis. It is possible to perforn immunohistochemical analysis on the SF sediment. Amyloid arthropathy can therefore be adde to the list of conditions in which synovial fluid examination can be clinically helpful.

Key words: $\beta_{2}$ microglobulin, potassium permanganate, amyloid arthropathy, immunohisto 3 chemical analysis.

The diagnosis of synovial amyloidosis is based upon the demonstration of amyloid in synovial tissue. ${ }^{1}$ In 1973 Gordon $e t$ al showed the presence of amyloid in small fragments of villi in the synovial fluid (SF) in three patients with rheumatoid-like polyarthritis, who were in fact affected by amyloid arthropathy associated with myeloma. ${ }^{2}{ }^{3}$ Since then no new publications have appeared confirming the usefulness of the method. We have studied a group of patients with chronic renal failure and amyloid arthropathy undergoing periodical haemodialysis ${ }^{4}$ in order to relate SF findings to those of synovial biopsy.

\section{Materials and methods}

We have studied the SF in seven patients with chronic renal failure undergoing dialysis (four men, three women; mean age 51 years; range 33-62 years)

Accepted for publication 22 September 1986

Correspondence to Dr J Muñoz-Gómez, Servicio de Reumatología. Hospital Clínico y Provincial. Cl Villarroel, 170, 08036Barcelona, Spain. diagnosed as suffering from synovial amyloidosis be means of synovial biopsy. The period of haemo 3 dialysis varied from five to 14 years, mean nine years. (Table 1). The aetiology for their chronic renas failure was glomerulonephritis (two patients), back flow hydronephrosis (one patient), nephroangios sclerosis (one patient), chronic nephritis (one patient), and unknown (two patients). No patien had renal amyloidosis. Ten consecutive patients (three men, seven women; mean age 50 years; range 30-75 years) with seronegative mono- or oligos arthritis of more than one year's duration, in whonf synovial biopsy had been performed for diagnostie purposes, served as a controls.

Synovial samples and centrifuged synovial tluis sediments were fixed in $10 \%$ formol saline, embed ${ }^{-}$ ded in paraffin, and the sections stained with Cong red and studied under polarising microscopy for the green birefringence typical of amyloidosis (Fig. 1) The samples from patients with chronic renal failure who were undergoing dialysis were treated wite potassium permanganate by Wright's technique 
Table 1 Amyloid in synovial fluid and synovial membrane

\begin{tabular}{|c|c|c|c|c|c|c|c|c|}
\hline \multirow{2}{*}{$\begin{array}{l}\text { Patient } \\
\text { No }\end{array}$} & \multirow{2}{*}{$\begin{array}{l}\text { Age } \\
\text { (years) }\end{array}$} & \multirow[t]{2}{*}{ Sex } & \multirow{2}{*}{$\begin{array}{l}\text { Dialysis } \\
\text { (years) }\end{array}$} & \multicolumn{2}{|l|}{ Amyloid } & \multirow{2}{*}{$\begin{array}{l}\text { Potassium } \\
\text { permanganate } \\
\text { synovial } \\
\text { fluid }^{*}\end{array}$} & \multicolumn{2}{|c|}{$\beta_{2}$ Microglobulin } \\
\hline & & & & $\begin{array}{l}\text { Synovial } \\
\text { membrane }\end{array}$ & $\begin{array}{l}\text { Synovial } \\
\text { fluid }\end{array}$ & & $\begin{array}{l}\text { Synovial } \\
\text { fluid }\end{array}$ & $\begin{array}{l}\text { Synovial } \\
\text { membrane }\end{array}$ \\
\hline 1 & 59 & $\mathbf{M}$ & 9 & + & + & + & + & \\
\hline 2 & 48 & $\mathbf{M}$ & 10 & + & + & + & + & \\
\hline 3 & 47 & $\mathbf{M}$ & 5 & + & + & + & ND & Wrist \\
\hline 4 & 54 & $\mathbf{M}$ & 8 & + & + & + & + & $\begin{array}{l}\text { Hip (also } \\
\text { capsule) }\end{array}$ \\
\hline 5 & 62 & $\mathbf{F}$ & 9 & + & + & + & + & Knee \\
\hline 6 & 33 & $\mathbf{F}$ & 14 & + & - & $\begin{array}{l}\text { Insufficient } \\
\text { quantity }\end{array}$ & ND & \\
\hline 7 & 55 & $\mathbf{F}$ & 8 & + & + & + & + & \\
\hline
\end{tabular}

* +indicates Congophilia resistant to pretreatment with potassium permanganate.

$\mathrm{ND}=$ not done.

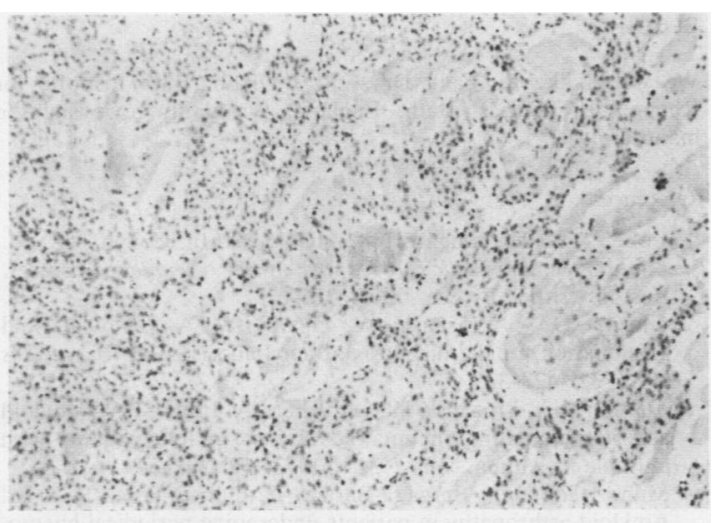

Fig. 1a

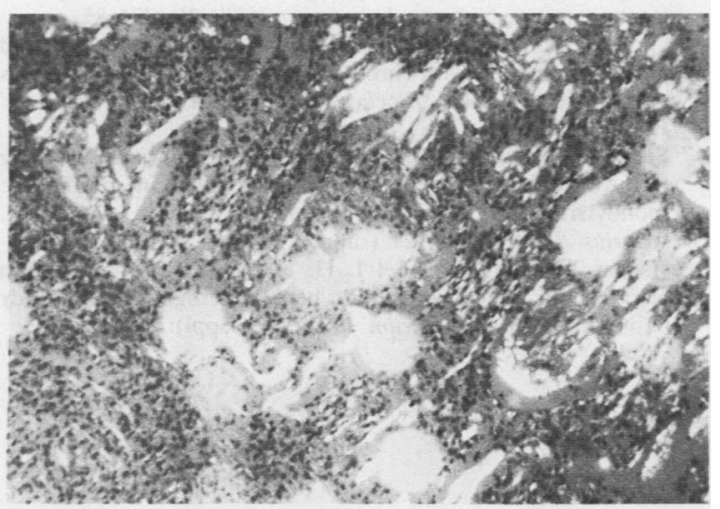

Fig. 1b

Fig. 1 Synovial fluid sediment after centrifugation: (a) multiple deposits of amorphous material Congo red positive; (b) intense green birefringence under polarising microscopy. (Congo red.)
Immunohistochemical analysis was carried out by the peroxidase-antiperoxidase method and by the avidin-biotin technique using anti- $\beta_{2}$ microglobulin antibody (DAKO). For statistical analysis the P4F program of the BMDP (California University) was used and proportions were compared with the McNemar test.

\section{Results}

In six of the seven patients with amyloid positive synovial biopsy specimens the SF showed the presence of amyloid (Table 1). No amyloid was found in the synovial tissue or fluid in the 10 patients in the control group.

In our patients the sensitivity of the study of SF with respect to synovial biopsy specimen was $87 \cdot 7 \%$. In patient No 6 (amyloid positive in synovial tissue and negative in fluid) the amount of SF was small $(2 \mathrm{ml})$, which might explain the absence of villous fragments; nevertheless, in other patients not included in this series we have found amyloid in similar amounts of SF. There were no statistically significant differences between the findings of the synovial biopsy and those of the SF (McNemar test).

The finding of amyloid in SF proved to be highly reproducible because on examining different samples of SF from the same biopsied joint over long periods of time (average eight months) amyloid was always found to be present (Table 2). The examination of other affected joints in the same patient always showed amyloid in the SF (17 samples from six patients), thus showing that the articular disorder was generalised (Table 2).

The amyloid showed a Congophilia resistance to treatment with potassium permanganate in the synovial fluid sediments of all the patients studied, a property apparently shared with AL amyloid (Fig. 1) 
Table 2 Amyloid in the synovial fluid of the joints studied

\begin{tabular}{llll}
\hline $\begin{array}{l}\text { Patient } \\
\text { No }\end{array}$ & Joint & $\begin{array}{l}\text { Number of } \\
\text { times studied }\end{array}$ & Amyloid \\
\hline 1 & R shoulder & 3 & + \\
& L shoulder & 2 & + \\
& R knee* & 4 & + \\
& L knee & 3 & + \\
& R wrist & 1 & + \\
2 & R knee* & 3 & + \\
& L knee & 2 & + \\
3 & R knee & 2 & + \\
& L knee* & 1 & + \\
& R knee* & 2 & + \\
5 & L knee & 1 & + \\
& R knee* & 3 & + \\
& L knee & 2 & + \\
7 & R ankle & 1 & + \\
& R knee & 1 & + \\
& L knee & 2 & + \\
& R shoulder & 1 & + \\
\hline
\end{tabular}

*Joint biopsied.

The immunohistochemical analysis confirmed that the amyloid deposits of synovial fluid sediments contained $\beta_{2}$ microglobulin. In addition, $\beta_{2}$ microglobulin was demonstrated in synovial tissue (knee, wrist, hip) in the three patients in whom it was studied.

\section{Discussion}

Gordon et al showed similar findings in amyloid arthropathy associated with myeloma. ${ }^{2}$ In their study amyloid was found in the synovial tissue of the right wrist in three patients and in the SF of the joints studied (first patient, right wrist and right knee; second patient, left shoulder and both knees; third patient both shoulders). In our cases the amyloid arthropathy was associated with patients with chronic renal failure undergoing haemodialysis. It seems likely that amyloid would be found in the $\mathrm{SF}$ in any type of synovial amyloidosis. Recently Gejyo et al have found that amyloid laden tissue, obtained from a patient with chronic renal failure undergoing dialysis and with carpal tunnel syn- drome, contained $\beta_{2}$ microglobulin, ${ }^{6}$ suggesting tha amyloid arthropathy associated with haemodialysis: is due to the presence of $\beta_{2}$ microglobulin. This fact has been confirmed by immunohistochemical analye sis by others, ${ }^{78}$ and we have also been able to demonstrate it in the SF sediment of our patients

The high sensitivity $(88 \%)$ of SF examination wit regard to the synovial biopsy and the good repros ducibility of the method (showing the presence of amyloid in the SF in the same joint on severat occasions) show that the finding of amyloid i $\overrightarrow{0}$ synovial fluid is sufficient for a diagnosis of synoviag amyloidosis to be made. Immunohistochemică analysis of SF sediment may be useful to demons strate the presence of $\beta_{2}$ microglobulin, AA amyloid and both $x$ and $\lambda$ light chains. Amyloid arthropath can therefore be added to the list of conditions where synovial fluid examination can be clinicalf useful.

We would like to thank Dr A St J Dixon, Bath Institute for Rheumatic Diseases, Bath, England, for kindly reviewing the manuscript.

\section{References}

1 Cohen A S. The diagnosis of amyloidosis. In: Cohen A S, ed Laboratory diagnostic procedures in the rheumatic disease? Boston: Little, Brown, 1967; 326-61.

2 Gordon D A, Pruzanski W, Ogryzlo M A. Synovial flui申 examination for the diagnosis of amyloidosis. Ann Rheum DI 1973; 32: 428-30.

3 Gordon D A, Pruzanski W, Ogryzlo M A. Little M A. Amyloiß arthritis simulating rheumatoid disease in five patients with multiple myeloma. Am J Med 1973; 55: 142-54.

4 Muñoz-Gómez J, Bergadá-Barado E, Gómez-Pérez R, et ato Amyloid arthropathy in patients undergoing periodical haemodialysis for chronic renal failure: a new complication. An Rheum Dis 1985; 44: 729-33.

5 Wright J R, Cackins E, Humphrey R. Potassium permanganato reaction in amyloidosis. Lab Invest 1977; 36: 274-81.

6 Gejyo F, Yamada T, Odani S, et al. A new form of amyloo protein associated with chronic hemodialysis was identified 3 beta 2-microglobulin. Biochem Biophys Res Commun 1985 129: 701-6.

7 Sebert J L, Bardin T, Shirama T, Marie A, Fournier A, Kun D. Amyloidosis and beta 2-microglobulin in destructiog spondylarthropathies of hemodialysis patients [Abstract] Arthritis Rheum 1986; 29 (suppl): S49.

8 Bardin T, Kuntz D, Nöel L H, et al. Amyloid deposits hemodialysis patients react with beta 2-microglobulin antiboo [Abstract]. Arthritis Rheum 1986; 29 (suppl): S11. 